\title{
Prediction model for phenology of grapevine cultivars with hot water treatment
}

\author{
Sabrina Lerin(1), Daniel Santos Grohs( ${ }^{(2)}$, Marcus André Kurtz Almança( ${ }^{(3)}$, Marcos Botton(2), \\ Paulo Mello-Farias ${ }^{(1)}$ and José Carlos Fachinello(4)
}

\begin{abstract}
(1)Universidade Federal de Pelotas, Campus Universitário Capão do Leão, s/no, CEP 96900-010 Capão do Leão, RS, Brazil. E-mail: sabrinalerin@gmail.com, mello.farias@ufpel.edu.br (2)Embrapa Uva e Vinho, Rua Livramento, no 515, Caixa Postal 130, CEP 95701-008 Bento Gonçalves, RS, Brazil. E-mail: daniel.grohs@embrapa.br, marcos.botton@embrapa.br ${ }^{(3)}$ Instituto Federal de Educação, Ciência e Tecnologia do Rio Grande do Sul, Campus Bento Gonçalves, Avenida Osvaldo Aranha, no 540, Juventude da Enologia, CEP $95700-206$ Bento Gonçalves, RS, Brazil. E-mail: marcus.almanca@bento.ifrs.edu.br ${ }^{(4)}$ In memoriam.
\end{abstract}

\begin{abstract}
The objective of this work was to prepare a prediction model for the phenology of grapevine cultivars (Bordô, Cabernet Sauvignon, Moscato Embrapa, Paulsen 1103, SO4, and IAC 572) using hot water treatment. The heat treatment with hot water consisted of combinations of three temperatures $(50,53$, and $55^{\circ} \mathrm{C}$ ) and three time periods $(30,45$, and $60 \mathrm{~min}$ ), with or without previous hydration for $30 \mathrm{~min}$. After the treatments, the cuttings were planted in the field and their phenological development was evaluated during two months. The six studied cultivars presented different responses to the effects of the factors temperature and time, but did not differ significantly regarding hydration. It was possible to develop a mathematical model for the use of hot water treatment in grapevine cuttings, based on phenological development $\left(\mathrm{y}_{\text {phenology }}=48.268-0.811 \mathrm{x}_{1}-0.058 \mathrm{x}_{2}\right)$ and validated by the variables sprouting and root emission. From the developed model, it is recommended that the hot water treatment be applied in the temperature range between 48 and $51^{\circ} \mathrm{C}$ for cuttings of all cultivars.
\end{abstract}

Index terms: Vitis, cultural treatments, fruticulture, grapevine trunk diseases, production of seedlings, vegetative development.

\section{Modelo de previsão para fenologia de cultivares de videira com tratamento de água quente}

Resumo - O objetivo deste trabalho foi elaborar um modelo de previsão da fenologia de cultivares de videira (Bordô, Cabernet Sauvignon, Moscato Embrapa, Paulsen 1103, SO4 e IAC 572) com uso de tratamento de água quente. $\mathrm{O}$ tratamento térmico com água quente consistiu de combinações de três temperaturas $(50,53$ e $\left.55^{\circ} \mathrm{C}\right) \mathrm{com}$ três intervalos de tempo $(30,45$ e $60 \mathrm{~min})$, com ou sem hidratação prévia por 30 min. Após os tratamentos, as estacas foram plantadas a campo e seu desenvolvimento fenológico foi avaliado por dois meses. As seis cultivares estudadas apresentaram respostas distintas quanto à influência dos fatores temperatura e tempo, mas não diferiram significativamente quanto à hidratação. Foi possível desenvolver um modelo matemático para uso do tratamento de água quente em estacas de videira, baseado no desenvolvimento fenológico $\left(\mathrm{y}_{\text {fenologia }}=48,268-0,811 \mathrm{x}_{1}-0,058 \mathrm{x}_{2}\right)$ e validado com as variáveis brotação e emissão de raízes. Recomenda-se, a partir do modelo desenvolvido, que o tratamento de água quente seja aplicado na faixa de temperatura entre 48 e $51^{\circ} \mathrm{C}$ para estacas de todas as cultivares.

Termos para indexação: Vitis, tratos culturais, fruticultura, doenças de tronco da videira, produção de mudas, desenvolvimento vegetativo.

\section{Introduction}

One of the main factors limiting grapevine productivity and longevity are grapevine trunk diseases, which are considered to be the most destructive in producing regions around the world (Bertsch et al., 2013). In 2012, the cost of replanting grapevine seedlings worldwide was estimated at $\$ 1.5$ billion per year (Hofstetter et al., 2012).
The pathogens that cause these diseases colonize the xylem and phloem of plants (Bertsch et al., 2013), and several of them have been found in the state of Rio Grande do Sul, Brazil: Ilyonectria macrodidyma, I. robusta, and Cylindrocarpon pauciseptatum (blackfoot disease) by Santos et al. (2014); Cylindrocarpon sp., Phaeoacremonium sp. (Petri and Esca diseases), Verticillium sp., Botryosphaeria sp., Fusarium 
oxysporum f.sp. herbemontis (Fusariose), Graphium sp., and Cylindrocladium sp. by Garrido et al. (2004); and Phaeomoniella chlamydospora (Petri and Esca diseases) by Almança et al. (2013).

The symptoms of these diseases usually consist of leaf necrosis, reduced growth and production, and, in more severe cases, the death of the grapevines (Newsome, 2012). The dissemination of contaminated propagation material (rooted cuttings and/or grafted seedlings) has been reported as the main form of dispersal of grapevine trunk diseases (Aroca et al., 2010).

Different strategies to control these phytopathogens have been evaluated, such as chemical and biological control (Fourie \& Halleen, 2004) and the use of hot water treatment (HWT). The latter is an efficient method for the control of pathogens that cause trunk diseases in propagation material (Gramaje \& Armengol, 2012; Bleach et al., 2013), when compared with the use of fungicides, because it allows treating inside the material where the pathogens are located. It should be noted that, in Brazil, there are no chemical or biological products registered for the control of phytopathogens associated with grapevine trunk diseases.

According to Waite et al. (2015), the use of HWT is a practice that may contribute to the phytosanitary quality of propagation material. However, attention is needed regarding the sensitivity of the vegetative material to HWT (Waite \& Morton, 2007; Gramaje et al., 2009), which can affect its viability and quality. These effects may vary depending on factors such as cultivar, growth conditions (climate in the growing region), development of the parent plant, type of material used by the nursery (stakes or rooted cuttings), storage conditions, hydration of cuttings before planting, and growth conditions after callus formation (Crocker \& Waite, 2004; Waite \& May, 2005). Besides taking into account this variation, in order for a technique to be adopted in a productive system such as a nursery for seedling production, it is important to use instruments that facilitate the understanding of these variations and integrate knowledge, such as the modeling of agricultural events (Corrêa et al., 2011).

The modeling of agricultural events is used to quantify and predict the effect of certain variables on crop development, to verify hypotheses, and to improve and integrate knowledge to be used as a tool in decision-making (Corrêa et al., 2011). These types of models are developed by adjusting mathematical equations using statistical tools, such as multiple linear regression, to predict, for example, the development of a culture, among other aspects (Corrêa et al., 2011). However, there are no reports in the literature regarding the use of mathematical modeling to predict the effects of HWT on the vegetative material of grapevines, and this is the first known study to evaluate the use of HWT on grapevines in Brazil.

Due to the concerns of international researchers about the viability of propagating material when using HWT in grapevines (Crocker \& Waite, 2004; Waite \& May, 2005), it is necessary to study the possible negative effects on the rootstocks and canopy cultivars used in each growing condition. Therefore, because of the lack of studies on the grape cultivars and rootstocks (e.g. IAC 572) widely used in Brazil, such as Vitis labrusca and hybrid species, a tool, such as mathematical modeling, is crucial to evaluate and validate the use of HWT in Brazilian conditions, since it allows predicting the phenological behavior of other cultivars regarding HWT without the need to conduct experiments with plants, saving time and resources.

The objective of this work was to prepare a prediction model for the phenology of grapevine cultivars (Bordô, Cabernet Sauvignon, Moscato Embrapa, Paulsen 1103, SO4, and IAC 572) using hot water treatment.

\section{Materials and Methods}

The experiment was carried out with cuttings from six grapevine cultivars: three rootstocks - Paulsen 1103 (Vitis berlandieri Planch. x V. rupestris Scheele), SO4 ( $V$. berlandieri $\mathrm{x} V$. riparia Wall.), and IAC $572[\mathrm{~V}$. tiliifolia Humb. \& Bonpl. ex Schult. x '101-14 Mgt' ( $V$. riparia $\times$ $V$. rupestris); and three canopy cultivars - Cabernet Sauvignon ( $V$. vinifera L.), Bordô ( $V$. labrusca L.), and Moscato Embrapa, an interspecific hybrid, originated from a cross between the Couderc 13 [V. licencumii $\mathrm{x}(V$. vinifera $\mathrm{x} V$. rupestris $)] \mathrm{x}$ July Muscat ( $V$. vinifera) cultivars.

The propagation material was taken from the Embrapa Uva e Vinho clonal garden, located in the municipality of Bento Gonçalves, in the state of Rio Grande do Sul, Brazil, and was kept in a cold chamber until the treatments were applied. Sixteen cuttings, with an average of $25 \mathrm{~cm}$ in length and three buds, were 
used for each treatment and cultivar. The treatments consisted of the complete immersion of the cuttings at three different temperatures $\left(50,53\right.$, and $\left.55^{\circ} \mathrm{C}\right)$ during three time intervals $(30,45$, and $60 \mathrm{~min})$ based on the methodology described in Gramaje et al. (2009). An additional factor was that the cuttings were hydrated or not prior to the HWT for $30 \mathrm{~min}$, with total immersion of the cuttings in a tank containing water at room temperature, as adapted from the study by Gramaje \& Armengol (2012).

For the treatments, a stainless steel tank, developed by Embrapa Uva e Vinho, equipped with two heaters and a thermostat, was used to control the temperature, which was measured before the treatments were performed. During the treatments, the temperature was constantly monitored using a portable digital thermometer with five Penta III sensors (Full Gauge Controls, Canoas, RS, Brazil).

After the treatments were applied, the cuttings were hydrated for 12 hours before being planted ungrafted in the field. The phenology of the cuttings was checked weekly in alignment with EPPO crop... (1984), and, at the end of the experiment, the number of cuttings that sprouted (considering the presence of at least one open leaf) and of roots were determined.

The experiment was carried out in the field at Embrapa Uva e Vinho, from September to November 9, 2014, totaling 60 days of evaluation from planting of the cuttings, which was considered sufficient time to observe the viability of the material after the treatments. The experimental design was a mixed model. The Bordô, Moscato Embrapa, Cabernet Sauvignon, Paulsen 1103, SO4, and IAC 572 cultivars corresponded to the random factors, and hydration, temperature, and time of HWT were the fixed factors. The fixed factors were part of a randomized complete block design with 16 subsamples (cuttings) in the main plot, in a $2 \times 3 \times 3$ factorial arrangement. The first factor was hydration (with and without), the second was temperature $\left(50,53\right.$, and $\left.55^{\circ} \mathrm{C}\right)$, and the third was time $(30,45$, and $60 \mathrm{~min})$. The random factors were conducted in the form of individual trials and were analyzed together. There was a period of 60 days between the application of the treatments and the assessments.

For the preparation of the phenology prediction model, only the last evaluation date was considered, and a weighted average was obtained for the phenological stage of the 16 subsamples. All the data were subjected to the exploratory analysis using the KolmogorovSmirnov test, at $5 \%$ probability, to remove atypical values.

The methodology for the development of the generic model was based on the classical multiple linear regression adjustment, according to the following expression, adapted from Levine et al. (2005): $\mathrm{yi}=\mathrm{a}+\mathrm{b}_{1} \mathrm{x}_{1}+\mathrm{b}_{2} \mathrm{x}_{2}+\ldots+\mathrm{b}_{\mathrm{k}} \mathrm{x}_{\mathrm{k}}$, in which yi is the phenological stage; $a$ is the constant coefficient; $b_{1}$ is the temperature coefficient; $b_{2}$ is the time coefficient; and $\mathrm{x}_{\mathrm{k}}$ is the temperature $\left({ }^{\circ} \mathrm{C}\right)$.

The model was constructed by following these steps: first, the model was adjusted independently for each cultivar, subjected or not to hydration, using the $r$ and Durbin-Watson values to verify the quality of the models in relation to homoscedasticity and autocorrelation; then, the models predicted for each cultivar, within each form of pre-planting hydration, were compared by the t-test, at $5 \%$ probability, using the confidence intervals (CIs) of the predicted values; and, finally, the range of the predictive temperature for the phenological stage with the same values as those obtained in the control (maximum possible phenological stage) was determined.

The validation of the model was performed by the joint analysis of the predicted temperature ranges of the maximum phenological stage and of the validation variables (maximum sprouting and maximum rooting) for the six cultivars, subjected or not to hydration. This comparison was done using the t-test, at $5 \%$ probability, of the mean values of the temperature range (separated into maximum, average, and minimum temperatures) with their respective standard errors.

In order to verify the difference between cultivars, the values predicted from the equations were compared by the t-test, at $5 \%$ probability, for each variable. No significant difference was observed between cultivars for three studied variables, which made it possible to prepare a general equation for each variable and its respective temperature tolerance limits. The statistical analysis was performed using the software IBM SPSS, version 24 (IBM Corporation, Armonk, NY, USA).

\section{Results and Discussion}

Regarding phenology, the relationship between temperature and time of exposure in HWT, without

Pesq. agropec. bras., Brasília, v.52, n.10, p.887-895, out. 2017 DOI: 10.1590/S0100-204X2017001000008 
hydration, was multiple for the Cabernet Sauvignon, Paulsen 1103, SO4, and IAC 572 cultivars, i.e., an effect of temperature and treatment time was observed (Table 1). For the treatment with hydration, this response occurred for the Cabernet Sauvignon and Moscato Embrapa cultivars. For both the treatments with and without hydration, the CI of the equations for each cultivar did not differ, indicating that the phonological response, i.e., phenological evolution according to the EPPO crop... (1984) scale, was independent of the tested genotype when subjected to HWT, which allowed the development of a general model for the six grape cultivars evaluated at the initial stage of propagation (60 days). This is important since there are no known studies in the international literature on the effect of HWT on grapevine phenology.

The mean coefficient of the equation was determined, and the following global model was obtained: $\mathrm{y}_{\text {phenology }}=48.268-0.811 \mathrm{x}_{1}-0.058 \mathrm{x}_{2}$, which allowed predicting the effect of HWT on the agronomic variables of Vitis spp., in order to help in decisionmaking regarding the temperature and time to be adopted in the application of HWT in grapevine cuttings.

Likewise, the mean $r$ and Durbin-Watson values obtained showed that the degree of confidence of the model was adequate. The values of the $r$ coefficient of multiple linear correlation, limited between $-1 \leq \mathrm{r} \geq+1$, when close to +1 or -1 , indicated a strong correlation between the variables. Consequently, from the values observed in Tables 1, 2, and 3, a direct correlation was found for all cultivars for the three variables analyzed.

The critical Durbin-Watson values, considering two variables (k: 2) and 16 observations (n: 16), were between $d_{L}=0.982$ and $d_{U}=1.539$, with a probability of $5 \%$, i.e., values below $d_{L}=0.982$ evidence a positive correlation between errors, while values above $\mathrm{d}_{\mathrm{U}=1.539}$ indicate that there is no positive correlation between errors. By analyzing the values presented in Tables 1, 2, and 3, it can be observed that the average Durbin-Watson values for phenology, sprouting, and root emission were mostly inconclusive, which could be solved with a higher number of observations (replicates) (Field, 2009).

The analysis of the variable sprouting (number of cuttings with sprouts) showed a significant effect of temperature and time on the Moscato Embrapa, Cabernet Sauvignon, and Paulsen 1103 cultivars, subjected or not to hydration (Table 2). The sprouting of the Bordo cultivar and of the rootstocks of the SO4 and IAC 572 cultivars was affected only by temperature. The results obtained for the Paulsen 1103 and Cabernet Sauvignon cultivars corroborate those of Akgül et al. (2016), who evaluated the temperatures of 51,52 , and $53^{\circ} \mathrm{C}$ for 30 or $45 \mathrm{~min}$ and found a reduction in sprouting with increasing temperature and time of exposure to HWT.

For the variable root emission (number of cuttings with roots), a multiple response (effects of temperature and time of treatment) was also observed for the Moscato Embrapa, Cabernet Sauvignon, and Paulsen 1103 cultivars, when not hydrated. When hydrated, only the Moscato Embrapa and Paulsen 1103 cultivars were significantly affected (Table 3). Temperature was the only factor that affected the root emission of the rootstocks of the SO4 and IAC 572 cultivars, subjected or not to hydration.

The temperature ranges were compared between the treatments with and without pre-HWT hydration, as well as between cultivars. Assuming that there was not enough variability for significant differences to occur in these treatments, it was considered that the global model was true and that it could be used in a unique way (Table 4).

No significant differences were found between the estimated temperature models for the six cultivars tested (Table 4). These results are in agreement with those of Gramaje et al. (2009), who used combinations of HWT ranging from 50 to $54^{\circ} \mathrm{C}$ for 30,45 , or $60 \mathrm{~min}$. The authors reported a small variability in the percentage of sprouting and in the mass of the aerial part of the plant (individual comparisons for each treatment and comparisons with other cultivars) in rootstocks of the $41 \mathrm{~B}$ Millardet et de Grasset (B Mgt), Ruggeri 140, Couderc 161-49, Paulsen 1103, and Richter 110 cultivars; in the combinations of $41 \mathrm{~B}$ Mgt, Ruggeri 140, Couderc 161-49, Paulsen 1103, and Richter 110; and in the combinations Bobal/Paulsen 1103, Merlot/Richter 110, Tempranillo/Richter 110, and Tempranillo/Couderc 161-49.

The developed model enables the standardization of only one HWT protocol. Despite this, the individual models presented in Tables 1, 2, and 3 present cases of cultivars with adjustment quality values ( $\mathrm{r}$ and DurbinWatson) considered below the standard. This behavior is expected when working with multivariate systems 

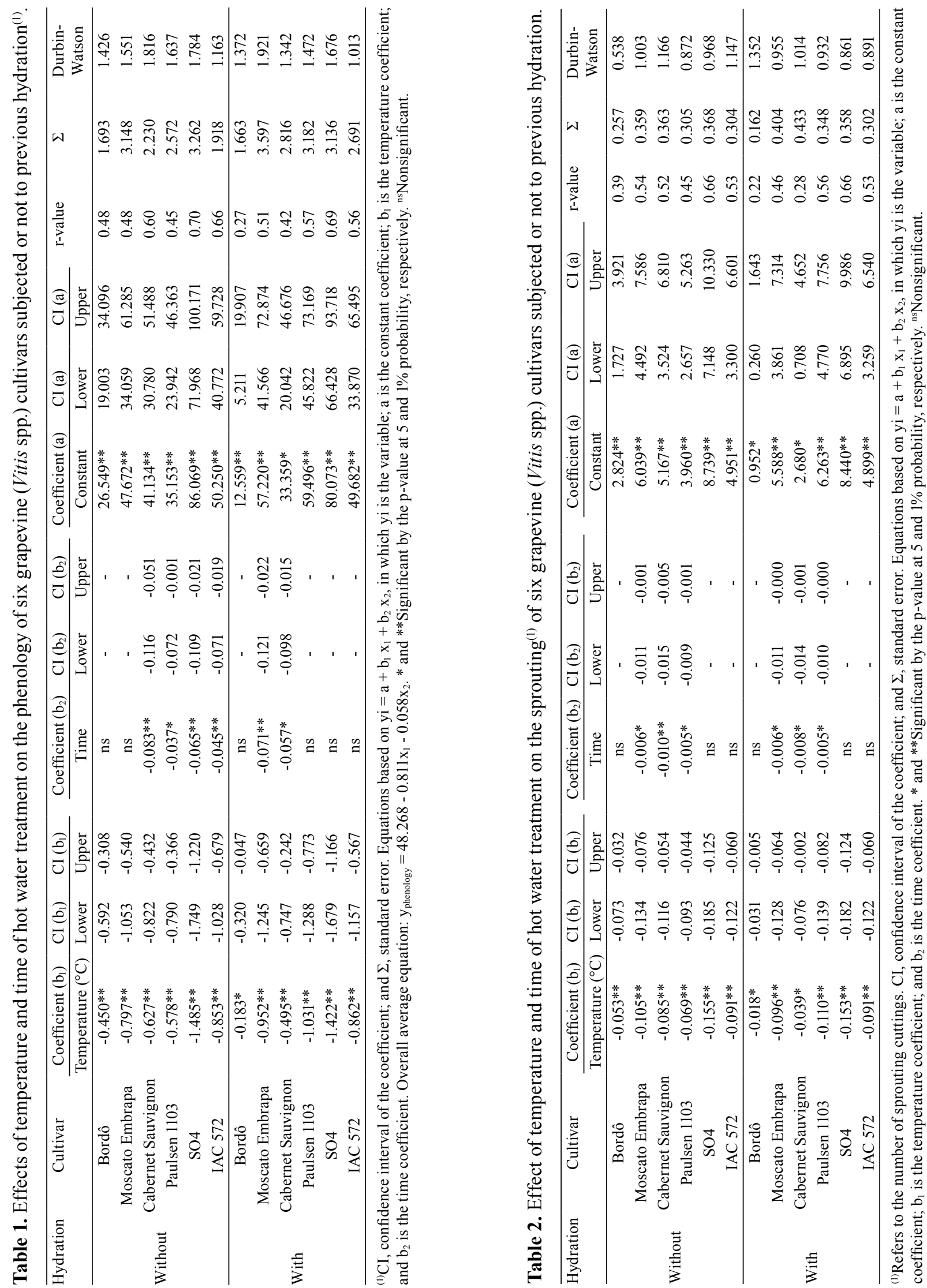


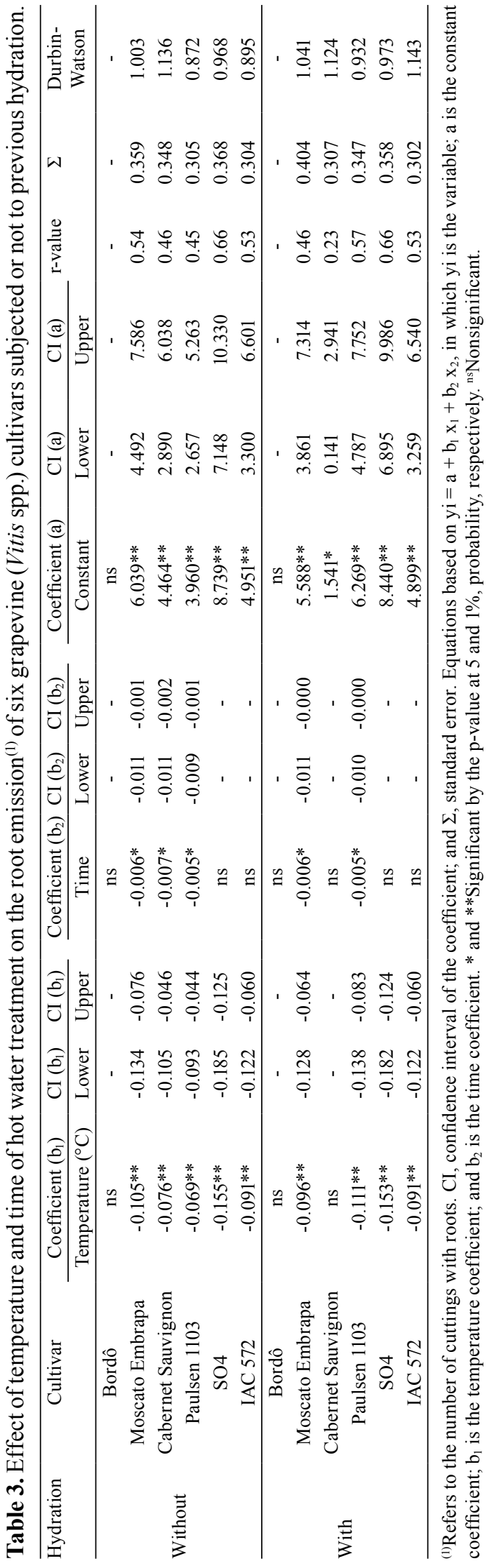

Pesq. agropec. bras., Brasília, v.52, n.10, p.887-895, out. 2017 DOI: 10.1590/S0100-204X2017001000008 in the field environment. However, the risk of an incorrect prediction was overcome by using the $\mathrm{CI}$ as a parameter to estimate a predicted temperature range, i.e., a prediction based on the CI encompasses $95 \%$ of the predicted results, which allows a high level of confidence in the use of the model and in the control of the experimental error. The values shown in Tables 1 , 2 , and 3 were used to define the maximum, minimum, and average values for each cultivar (Table 4). Because there were no significant differences between the assessed cultivars, the prediction interval was based on the average of temperatures between them, which corresponded to the minimum and maximum limits of 48 and $51^{\circ} \mathrm{C}$, respectively.

There was also no significant difference regarding the factor hydration for the three analyzed variables (Table 4). In the present study, no effect of prehydration for 30 min prior to HWT was observed; however, according to Waite \& May (2005), hydration for 4 hours prior to HWT favored the development of calli in the base of the cuttings of the Chardonnay cultivar, whereas hydration for 15 hours, or nonhydration, did not favor the formation of basal calli. Pre-hydration prior to HWT still causes discussions among researchers using this technique, since very long periods of HWT can damage plant material and allow phytopathogens to enter via water or the surface of the material itself and penetrate through the damaged parts of the plant (Waite et al., 2013).

In a study carried out in Australia, Waite \& May (2005) found greater calli development in Chardonnay cuttings subjected to 4 hours of hydration than in cuttings subjected to 15 hours of hydration; however, there was no significant difference compared with the control (without pre-hydration). The results found in the present study for the Cabernet Sauvignon cultivar corroborate those of Waite \& May (2005), who did not observe a significant effect of hydration on the development of calli and roots for the same cultivar.

Although temperature and time, with and without hydration, affected the response of each cultivar (Tables 1, 2, and 3) regarding temperature ranges, the behavior (tolerance to temperature) of the six grapevine cultivars in relation to the three analyzed variables was similar (Table 4). Using the temperature limit predicted by the equations for each cultivar, the minimum, average, and maximum values for each variable were determined, as follows: 48,49 , and $51^{\circ} \mathrm{C}$ 


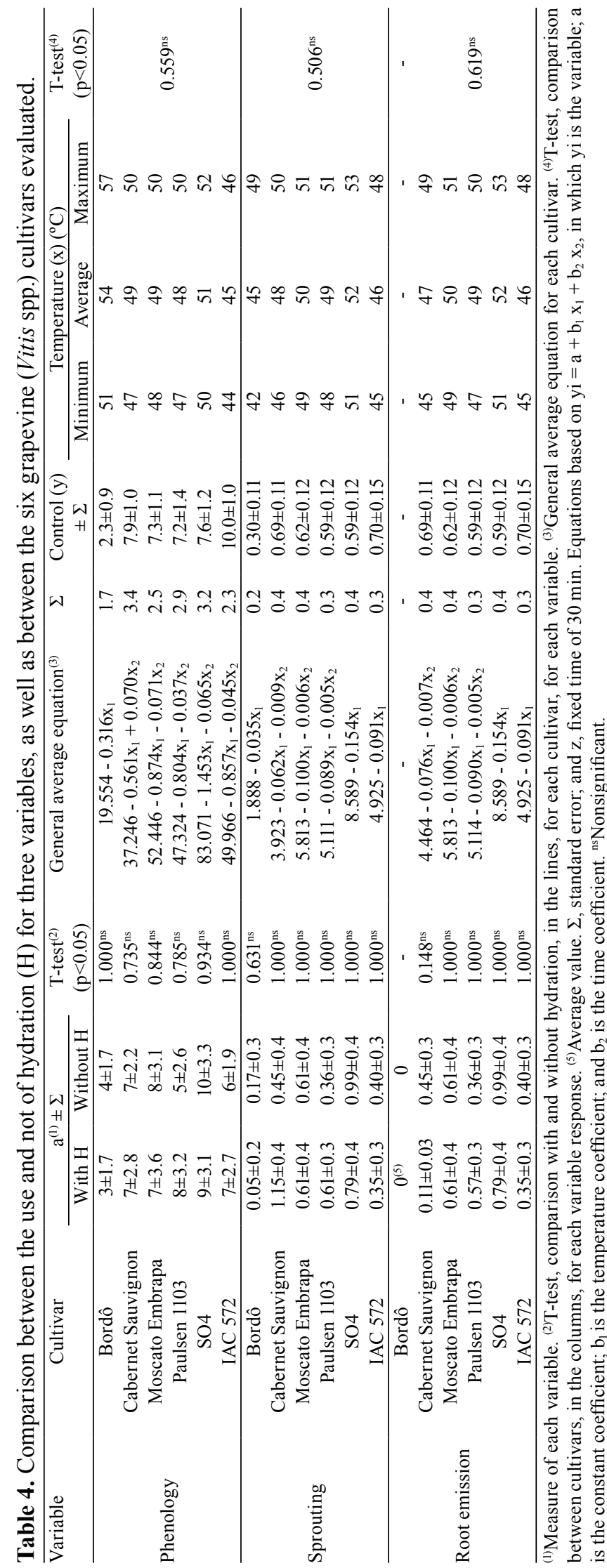

for phenology; 46,48 , and $51^{\circ} \mathrm{C}$ for sprouting; and 45 , 49 , and $52^{\circ} \mathrm{C}$ for root emission.

In the final condition, all the cultivars were similar, independently of their peculiarities, which is in alignment with the results obtained by Waite \& May (2005) for Chardonnay and Cabernet Sauvignon. The authors initially observed different responses for each cultivar in isolation, but, at the end of the experiment, found similar root emission behavior between the cultivars. According to a review by Waite \& Morton (2007), the different sensitivity of $V$. vinifera cultivars to HWT has been studied since the 1990s, when this treatment started to be introduced as a standard practice in nurseries. Researches have shown that some cultivars, such as Pinot Noir, Chardonnay, Reisling and Merlot, are more sensitive to HWT than, for example, Cabernet Sauvignon, and that they present a delay at the beginning of sprouting and root emission; however, at the end of the evaluation period, they show similar values to those of the plants that did not receive HWT. Despite these findings, this is the first known report of the effect of HWT on V. labrusca cultivars, their hybrids, and rootstock.

Studies with the rootstocks of the B Mgt 101-14 and Teleki 5C $(V$. berlandieri $\times V$. riparia $)$ cultivars by Bleach et al. (2013), in New Zealand, showed that there was no growth retardation or death of the cuttings treated at $48.5^{\circ} \mathrm{C}$, for $30 \mathrm{~min}$.

In the present study, the similar behavior of the studied cultivars in relation to HWT could have been a consequence of their level of thermo-tolerance due to the climate of the region, a factor already verified by Crocker \& Waite (2004). Therefore, it is necessary to conduct further scientific experiments to determine the significance of Brazilian conditions for the tested cultivars. The injuries caused by HWT are reported as being less common in hot climate regions than in cold ones because of the high level of thermo-tolerance credited to grapevines grown in hot regions (Crocker \& Waite, 2004). This has been attributed to the synthesis of "thermal shock proteins" by plants in hot climates, which makes them persist in dormancy and protects them during HWT (Crocker \& Waite, 2004). In terms of the variable root emission, the lowest and highest temperature tolerances were $45^{\circ} \mathrm{C}$ (minimum) and $52^{\circ} \mathrm{C}$ (maximum). These values are in alignment with those of studies conducted in other countries, where $\mathrm{HWT}$ at $50^{\circ} \mathrm{C}$, for $30 \mathrm{~min}$, did not inhibit root emission 
of the Chardonnay and Cabernet Sauvignon cultivars (Waite \& May, 2005).

The values for temperature tolerance limits that were predicted with the models are also consistent with the protocols used in other countries. The climatic conditions where grapevines are cultivated are affected by the combination of time and temperature in HWT. In cold climates, lower temperatures, such as $48^{\circ} \mathrm{C}$ for 30 min (Bleach et al., 2013), can be used; in moderate climates, $50^{\circ} \mathrm{C}$ for $30 \mathrm{~min}$ (Waite \& Morton, 2007); and, in hot climates, $53^{\circ} \mathrm{C}$ for $30 \mathrm{~min}$ (Gramaje et al., 2009). In Italy, in a three-year experiment, HWT at $52^{\circ} \mathrm{C}$, for $45 \mathrm{~min}$, showed a reduction in losses after cultivation at an acceptable level (0 to 20\%) compared with the control (Mannini, 2007).

\section{Conclusions}

1. The Bordô, Cabernet Sauvignon, Moscato Embrapa, Paulsen 1103, SO4, and IAC 572 grapevine (Vitis spp.) cultivars did not show significant differences regarding the phenological stage or hydration of the cuttings when subjected to hot water treatment.

2. A single model can be used to predict the phenological stage as a function of temperature and time of heat treatment in the initial phase of grapevine propagation, and the global model constructed is $\mathrm{y}_{\text {phenology }}=48.268-0.811 \mathrm{x}_{1}-0.058 \mathrm{x}_{2}$, in which $\mathrm{y}$ is the phenological development stage (scale note); $\mathrm{x}_{1}$ is the temperature $\left({ }^{\circ} \mathrm{C}\right)$; and $\mathrm{x}_{2}$ is the time ( $\left.\mathrm{min}\right)$.

3. As the temperature increases in relation to the temperature range $\left(48\right.$ to $51^{\circ} \mathrm{C}$ in $\left.30 \mathrm{~min}\right)$ or the exposure time increases, the phenological stage decreases.

\section{Acknowledgments}

To Embrapa Uva e Vinho and to Instituto Federal de Educação, Ciência e Tecnologia do Rio Grande do Sul (IFRS), for technical support; and to Conselho Nacional de Desenvolvimento Científico e Tecnológico (CNPq), for the PhD scholarship for the first author.

\section{References}

AKGÜL, D.S.; SAVAŞ, Y.; GÜNGÖR SAVAŞ, N.; YAĞCI, A. Effects of hot water treatments on growth of Botryosphaeriaceae fungi and bud vitality of grape scion and rootstocks in controlled conditions. Ege Üniversitesi Ziraat Fakültesi Dergisi, v.53, p.99-107, 2016.
ALMANÇA, M.A.K.; ABREU, C.M. de; SCOPEL, F.B.; BENEDETTI, M.; HALLEEN, F.; CAVALCANTI, F.R. Evidências morfológicas da ocorrência de Phaeomoniella chlamydospora em videiras no Estado do Rio Grande do Sul. Bento Gonçalves: Embrapa Uva e Vinho, 2013. 5p. (Embrapa Uva e Vinho. Comunicado técnico, 134).

AROCA, A.; GRAMAJE, D.; ARMENGOL, J.; GARCÍAJIMÉNEZ, J.; RAPOSO, R. Evaluation of the grapevine nursery propagation process as a source of Phaeoacremonium spp. and Phaeomoniella chlamydospora and occurrence of trunk disease pathogens in rootstock mother vines in Spain. European Journal of Plant Pathology, v.126, p.165-174, 2010. DOI: 10.1007/s10658009-9530-3.

BERTSCH, C.; RAMÍREZ-SUERO, M.; MAGNIN-ROBERT, M.; LARIGNON, P.; CHONG, J.; ABOU-MANSOUR, E.; SPAGNOLO, A.; CLÉMENT, C.; FONTAINE, F. Grapevine trunk diseases: complex and still poorly understood. Plant Pathology, v.62, p.243-265, 2013. DOI: 10.1111/j.1365-3059.2012.02674.x.

BLEACH, C.; JONES, E.; RIDGWAY, H.; JASPERS, M. Hot water treatment to reduce incidence of black foot pathogens in young grapevines grown in cool climates. Phytopathologia Mediterranea, v.52, p.347-358, 2013.

CORRÊA， S.T.R.; LORENÇONI, R.; DOURADO NETO, D.; SCARPARE, F.V.; VIVIAN, R.; RUIZ, E.T. Aplicações e limitações da modelagem em agricultura: revisão. Revista de Agricultura, v.86, p.1-13, 2011.

CROCKER J.; WAITE, H. Development of effective, efficient and reliable hot water treatments: GWRDC project SAR 99/4: Final project report. [Adelaide]: Grape and Wine research and Development Corporation, 2004.

EPPO CROP growth stage keys: grapevine. European and Mediterranean Plant Protection Organization Bulletin, v.14, p.295-298, 1984.

FIELD, A. Descobrindo a estatística usando SPSS. 2.ed. Porto Alegre: Artemed, 2009. 688p.

FOURIE, P.H.; HALLEEN, F. Proactive control of Petri disease of grapevine through treatment of propagation material. Plant Disease, v.88, p.1241-1245, 2004. DOI: 10.1094/ PDIS.2004.88.11.1241.

GARRIDO, L. da R.; SÔNEGO, O.R.; GOMES, V.N. Fungos associados com o declínio e morte de videiras no Estado do Rio Grande do Sul. Fitopatologia Brasileira, v.29, p.322-324, 2004. DOI: $10.1590 / \mathrm{S} 0100-41582004000300016$.

GRAMAJE, D.; ARMENGOL, J. Effects of hot-water treatment, post-hot-water-treatment cooling and cold storage on the viability of dormant grafted grapevines under field conditions. Australian Journal of Grape and Wine Research, v.18, p.158-163, 2012. DOI: 10.1111/j.1755-0238.2012.00185.x.

GRAMAJE, D.; ARMENGOL, J.; SALAZAR, D.; LÓPEZCORTÉS, I.; GARCÍA-JIMÉNEZ, J. Effect of hot-water treatments above $50^{\circ} \mathrm{C}$ on grapevine viability and survival of Petri disease pathogens. Crop Protection, v.28, p.280-285, 2009. DOI: 10.1016/j.cropro.2008.11.002.

HOFSTETTER, V.; BUYCK, B.; CROLL, D.; VIRET, O.; COULOUX, A.; GINDRO, K. What if esca disease of grapevine 
were not a fungal disease? Fungal Diversity, v.54, p.51-67, 2012. DOI: $10.1007 / \mathrm{s} 13225-012-0171-\mathrm{z}$.

LEVINE, D.M.; BERENSON, M.L.; STEPHAN, D. Estatística: teoria e aplicações usando o Microsoft Excel em português. 3.ed. Rio de Janeiro: LTC, 2005.

MANNINI, F. Hot water treatment and field coverage of mother plant vineyards to prevent propagation material from phytoplasma infections. Bulletin of Insectology, v.60, p.311-312, 2007.

NEWSOME, J. Grapevine trunk disease: a review. [S.1.], 2012. 20p. SANTOS, R.F. dos; BLUME, E.; MUNIZ, M.F.B.; HARAKAWA, R.; GARRIDO, L. da R.; REGO, C. Characterization of Campylocarpon pseudofasciculare associated with black foot of grapevine in southern Brazil. Phytopathologia Mediterranea, v.53,p.406-415,2014.DOI: 10.14601/Phytopathol_Mediterr-14045.

WAITE, H.; GRAMAJE, D.; WHITELAW-WECKERT, M.; TORLEY, P.; HARDIE, J. Soaking grapevine cuttings in water: a potential source of cross contamination by micro-organisms. Phytopathologia Mediterranea, v.52, p.359-368, 2013. DOI: 10.14601/Phytopathol_Mediterr-11555.

WAITE, H.; MAY, P. The effects of hot water treatment, hydration and order of nursery operations on cuttings of Vitis vinifera cultivars. Phytopathologia Mediterranea, v.44, p.144-152, 2005. DOI: 10.14601/Phytopathol_Mediterr-1791.

WAITE, H.; MORTON, L. Hot water treatment, trunk diseases and other critical factors in the production of high-quality grapevine planting material. Phytopathologia Mediterranea, v.46, p.5-17, 2007. DOI: 10.14601/Phytopathol_Mediterr-1857.

WAITE, H.; WHITELAW-WECKERT, M.; TORLEY, P. Grapevine propagation: principles and methods for the production of high-quality grapevine planting material. New Zealand Journal of Crop and Horticultural Science, v.43, p.144-161, 2015. DOI: $10.1080 / 01140671.2014 .978340$.

$\overline{\text { Received on November 4, } 2016 \text { and accepted on February 24, } 2017}$ 